\title{
SELF-IMAGE IN CHILDREN OF DIVORCED PARENTS
}

\author{
MSc Slagjana Angjelkoska, Psychologist, Center for Social Care, Gostivar, Macedonia \\ E-mail: as.anima@hotmail.com \\ Dr. Gordana Stankovska, Faculty of Philosophy, Institute for Psychology, State University in Tetovo, Macedonia \\ E-mail: g.stankovska@yahoo.com \\ MSc Dimitar Dimitrovski, Institute for Public Health, Skopje, Macedonia \\ E-mail: dimitar.5050dimitrovski@gmail.com
}

\author{
Received: November, 18.2015. \\ Revised: November, 30.2015. \\ Accepted: December, 04.2015. \\ Original Article \\ UDK 159.922.73.075:316.813.5(497.7)
}

\begin{abstract}
The family and its important role in the development of the child is the inspiration for many types of research that have the intention to emphasize certain aspects of family life and the consequences of the family relations in the development of the children.

The issue of this research is to find out if there is a connection between the conflict in the family, the divorce of the parents and self-concept in the children of early school age. The research is conducted on 30 children of single-parent families. The children of these single-parent families are children who have lived in families with conflicts and they have been direct or indirect participants in the conflict of the divorced parents.

In the process of research, we applied projective techniques: Machover which consists of drawing a person's figure, as well as a drawing a house and a tree-HTP (House-Tree-Person).The results are obtained through qualitative analysis and interpretation of each drawing particularly.

During the investigation the relation between the variables, it is confirmed that there is a considerable connection between the conflict in the family, the divorce of the parents and the self-concept in children. It is confirmed, during the process that the children of divorced parents from negative self-concept. In children of singleparent families it is indicated that this group of children in relation to the psychological picture for themselves presented the following characteristics: lowered EGO, mechanisms for defense, feeling of insecurity, low selfconfidence, aggressiveness, great virility, and caution.

Keywords: self-concept, mid-childhood, family, family atmosphere.
\end{abstract}

Corresponding Author

MSc Slagjana Angjelkoska, Psychologist, Center for

Social Care, Gostivar, Macedonia

E-mail: as.anima@hotmail.com

\section{INTRODUCTION}

The concept self-images are defined in different ways; according to (Cratch and Cratchfild, 1976) it represents a consciousness of oneself or a representation of the personal I (self-conception); according to other authors it is a self-esteem and, according to a third author (Olport) it represents the consciousness of the consciousness. Cratch and Cratchfild say that the individual has certain consciousness of himself i. e they in a certain manner understand and evaluate the personal I. Every individual is aware that he is a certain type of person who has some capabilities, skills, knowledge, has different convictions, values, attitudes, directed towards different aims and aspirations. The individual as well takes care about his relation with the surrounding i.e. what objects does he possess, in what social group does he belong, what is his social status, what is his social role, and how does he look like in the eyes of the other people. The development of the self-concept is very difficult and complex process. The self-concept develops throughout the life constantly under the influence of the inner capacities of the person and his social experience. During the earliest period of growing the child creates his trust in his parents. In the early childhood, the development of the self-concept depends on the way the adults react on the child's needs like hunger, thirst, sleep, and other basic needs. It also depends on the feeling of trust or entrusts in the surrounding. The sensibilities of the parents, as well as the parents' constant respond to the child's needs, are of great importance for the development of the positive self-concept.

The child finds out about himself throughout a game, and the relation to himself is created primarily on the basis of the parental reaction, the comments that are directed to- 
wards him by the parents and the other adult people.

Parents' comments, commendations, opinions, and punishments are decisive factors for creating a picture of himself as a worthy or less worthy person (Block, Block, and Gjerge, 1986).

The self-concept represents an overall consciousness of the individual about himself which integrates by observing and thinking about his own personality. It is formed during the childhood and throughout life becomes more enriched.

The role of the parents in the development of the child is primary. In the family, every member satisfies or at least expects to satisfy some of his conscious or unconscious emotional needs. In the family, the individual may feel accepted or rejected, happy and secure or depressed and insecure.

In the development of the personality of the child, the most important feeling is the feeling of security, feeling that the parents love him and take care about him (Rot 1980). The general atmosphere in the family is far more important than the individual behaviors of the parents to the child. The children of those families where there is an atmosphere of trust, love, and partnership's relations between the parents themselves and between the parents and the child will grow as a positive person. On the other hand, children that live in families where there are frequent conflicts between the parents will grow as persons with negative characteristics. The conflict between the parents brings to a conflict in the children themselves. By rule, the children love both their parents and they partially identify with both of them and because of that the conflict between the parents brings conflicts in the children themselves (Berger, 2002).

The divorce and the separation of the parents are hard for all the members of the family and the greatest victims are the children. The children in these families are victims of the conflict between their parents and they deserve special attention (Arendell, 2000). Every child is special having particular weaknesses, strength, flaws, and way of thinking. When the marriage falls apart and one of the parents leaves the home; the home and the life of the child will be filled with negative emotions. Creating a real picture of oneself according to the researchers of Elizabeth Harlok to a great extent depends on the relation of the parents to their child as well as the family atmosphere in which the child grows and develops. The family has a direct influence on the way the child creates an opinion of oneself and how will be perceived by the others and that influences directly the real or the unreal picture of oneself.

\section{MATERIALS AND METHODS}

The subject of this research is the influence of the negative family atmosphere that is produced by the frequent conflicts between the parents on the formation of the self-concept in children of these families. The broadly defined aim of this research is through analysis of children's drawings to find out the influence of the unfavorable family atmosphere on the psychological development of the child, as well as the influence of the separation of the parents on the picture that the child creates about himself. In the children's drawings their feelings; the conflicts they have with other people; emotional tension and other personal problems come to the surface. The drawing is used as a psycho-therapeutic means through which the mental problems and unsolved emotional conflicts appear and they are significant starting points in the psychotherapy.

Having in mind the complexity of the research, a general hypothesis of the research is defined.

General hypothesis: There is a connection between the conflict of the parents, the divorce and the picture of oneself in the children at early school age.

In order to reach the dependent variable picture of oneself to children of divorced parents, it was necessary to analyze all the reactions and the behavior which participated in its creation.

The independent variable that directly influences the formation of the picture for oneself in children of conflicting families is the relation of the parents, the constant conflict between the parents and the process of divorce of the spouses.

The participants that took part of the research are children from divorced parents. Data on children from divorced parents are received from the Center for Social Work, the department responsible for the issues of divorces. The psychologist works with each child individually, the test takes 60 minutes. Specified time refers to the introductory interview and giving instructions for work, the children are asked to draw two drawing one draw two human figures (male and female), and the second drawing to drawing a house and a tree. 
Children's characteristics that are conditions to be included in this research are:

-The age of the children is 6 to 11 years.

-The children have gone through the process of divorce

-The children are direct or indirect participants in the conflict between the parents

-The children do not suffer from hard chronicle illnesses.

-The children are intellectually developed according to their age.

Research was conducted on 50 children. In the process of the research, we applied two projective techniques: Machover (Machover, 1949) which consists of drawing a person's figure, as well as a drawing a house and a treeHTP (House-Tree-Person). It is a diagnostic procedure that requires very little time to apply, finds a good response in the subject as psycho- diagnostic technique in clinical psychology offers some information which is relevant to deep personality assessment. Assessment is carried out in several stages:

The first stage analyzes the details given in the drawing. List of items that are analyzed in the drawing is: head, body, legs, feet, mouth, eyes chin, ears, eyebrows, nose, hair, neck, shoulders, waist, hand, fingers, chest. Then the clothes and details: dress, suit, shoes, hat, stick.

In the second stage of the drawing are made a deeper analysis: which part of the sheet is drawn the figure, the size of the figure, the proportion of body parts.

HTP technique requires the children to draw a house and a tree, through analysis of the details: doors, windows, roof, door handle, the branches of the tree, the roots of the tree, gives information for conflicts, stress, emotional and social development.

In the processing of the drawings a qualitative analysis of the drawings is carried out and for each drawing analysis will be conducted about the concrete drawing obtained from the children of the divorced parents.

\section{RESULTS}

While we analyzed the drawings of the children whose parents are divorced, it can be stated that in this population in terms of the psychological development and formation of the picture of oneself great role has the family atmosphere in which the children live; the process of divorcing of the parents and the contacts of the children with the parents after the divorce. All these factors have a negative influence in the development of the self-concept and at the same time generally in the psychological development of the personality of the children. Characteristic is that the regular contacts with the parent influences the formation of an adequate self-concept that can be noticed in picture 1 where can be noticed that the drawing is adequate to the age of a 9-year old girl of divorced parents; however with regular contacts with the both parents, a noticeable separation from the social surrounding is present, but later she easily adapted to the new surroundings.

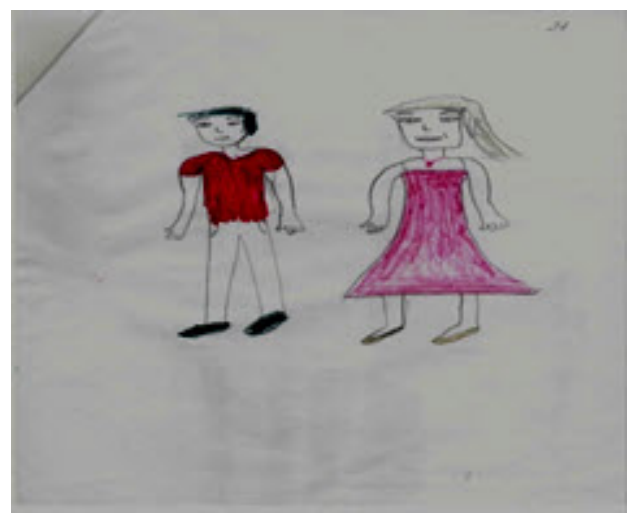

Picture 1. Image of the child on 9-year-old girl of divorced parents, but with regular contact with both parents

During the interpretation of the drawings of children from divorced families, we could notice that in this group of children a low control of impulses is present that determine the strength of the ego to defend from the pressure that is present in themselves. All that shows that the ego in this group of children is weakly organized, they have a low level of frustration control and the reactions are impulsive. The weak ego doesn't provide enough power to control the impulses and instincts. The impulses, especially the aggressive ones that are suppressed remain in them and are the reason for inner, suppressed aggression which is present in these children. Accumulated aggression causes the disintegrated ego. In picture 2 when the ego is disintegrated we follow the incapability of the ego to resist the hardship of the continuous suppressing of the unconscious impulses that lead to problems in the developing of the personality of the child. The reduced ego in this group of children is actually recognized through the great insecurity in themselves, low self-confidence, fear of social contacts insecurity in the social contacts and low self-confidence. 


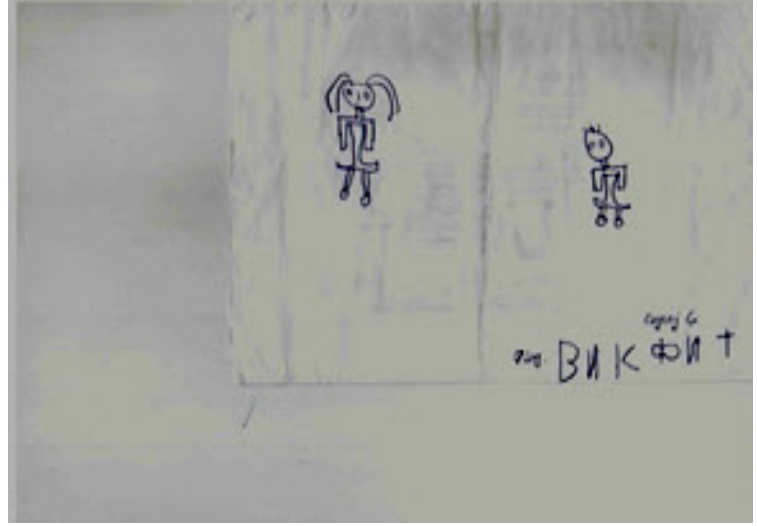

Picture 2. You can clearly see the presence of reduced ego in this child of divorced parents, drawing small figures and weak stalk reflect the reduced ego

In the picture 3 and 4 aggressiveness which is accumulated in this child who is at the age of 8 can be noticed and he has constant communication with the father and therefore in him a frustrating feeling appears along with suppressed aggressiveness, traumatic experience (the knot at the root of the tree) through which this kid went through is also the reason for aggressiveness present in him.

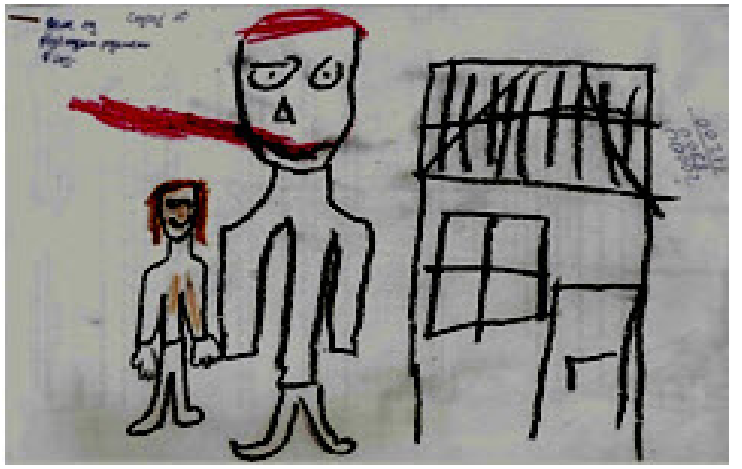

Picture 3. Image of child of 9 years, with limited social contacts

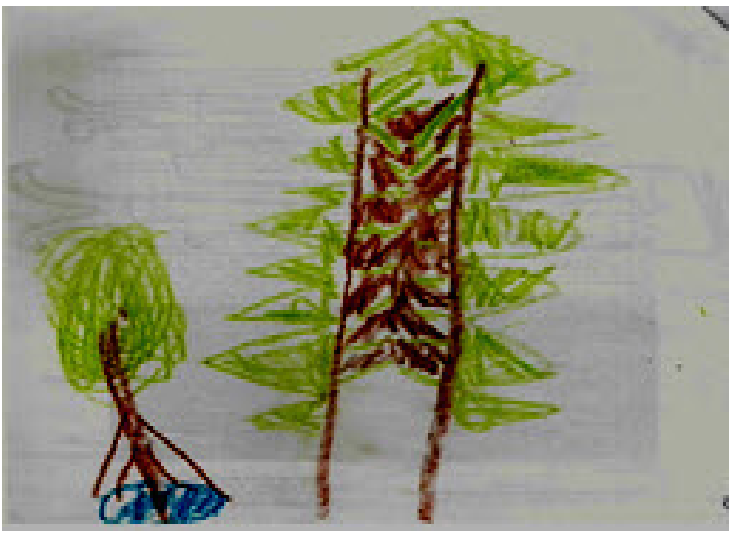

Picture 4. Image of child of 9 years and who has the interrupted communication with the father.

Picture 3 and picture 4 are images of a child of 9 years and who has the interrupted communication with the father.
Analyzing the self-concept in the children of early school age who come from families of divorced parents the following basic characteristics which define the psychological self-concept in this population can be recognized: they can be grouped in six categories: lowered ego- $67 \%$, mechanisms of defense- $43 \%$, feeling of insecurity- $46 \%$, low self-confidence- $46 \%$, aggressiveness- $40 \%$, increased virility and caution $-83 \%$. We can see that on figure 1 .

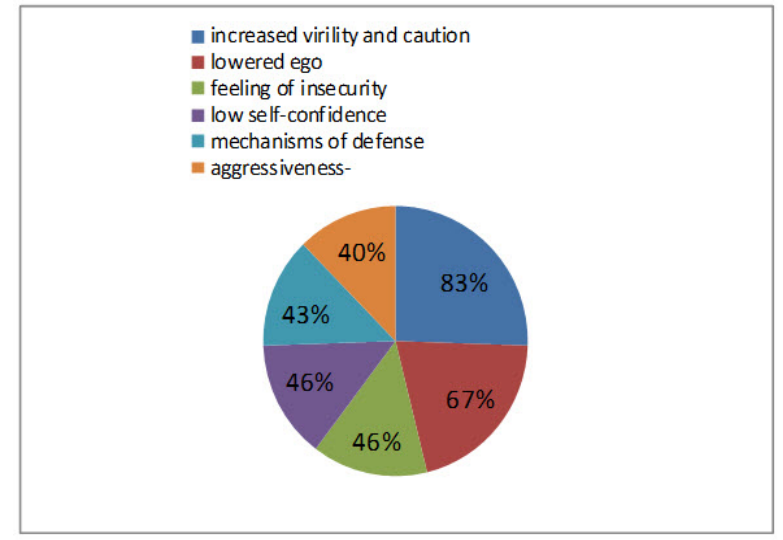

Figure 1. Psychological self-concept in children of divorced parents

\section{DISCUSSIONS}

The family is the place where the child should feel the first love of his parents. Life in the family has a great influence on the development of the child's personality, how you live in the family determine the parents. Dysfunctional relationships between parents are closely related to the dependence of the child, negativism, anger, and isolation of the child. What part of the person will have a child and what image they build yourself will depend on the family environment in which the child is formed as a person.

In our study, we found that the divorce had a negative effect on children's emotions. They felt stressed out, angry, frustrated or sad. At the same time, they feel abandoned, afraid, worried or guilty. They are more aggressive and impulsive, have lowered Ego and everything is changing in their life.

From the analysis of the drawings, it can be seen that these children apply certain mechanisms of defense as a mean that will serve the ego to avoid some danger, inner or outer, to solve the certain conflict. The regress as a most frequently used defensive mechanism in these children is related to the latent aggression which is present in the children and increases their impulsive reacting (Frojd, 
2004.). Their own needs and impulses are expressed in a motorist way and their behavior is characteristic for an earlier age. With this regressive way of behavior, the children give a signal to the parents that they are also present in their life with all their needs. The emotion which is expressed at that moment is expressed unexpectedly and with no control; in that way the child releases the extra energy.

From our results, it is easily noticeable that in this group of children the ego is lowered to a great extent which does not enable enough power to control their impulses and drives, especially the aggressive ones that remain suppressed. Accumulated aggression leads to disintegrated ego. It can also be seen that this group of children to great extent develops mechanisms for defense $(43 \%)$ in order to lower the anxiety. In the graph, it can be seen that on a considerable levels are the low self-confidence and the feeling of insecurity that also leads to reducing the possibility to reach balance in the psychological development at the personality of the child he overall atmosphere and the conflicting situation in which the children are present leads to appearance of high level of caution in sense of being insecure in the intentions of the people around them.

This whole range of characteristics in the psychological development of the child low self-confidence feeling of insecurity regressive behavior leads to the feeling that he is not loved, is needs are not met and the child has to suppress his needs and desires, and every negation of his needs means that he is rejected again by the parents. By that, it is proved the significance of the research that there is a connection between the family conflict and the formation of the picture of oneself in children of divorced parents.

\section{CONCLUSIONS}

Starting from the influence of the family atmosphere in which the child grows and develops on the basis of creating a self-concept, in this research general hypothesis was set which refer to the formation of self-concept in children whose parents are divorced.

According to the results of the analysis of the drawings we can extract the following conclusions:

1. Children of divorced parents have certain difficulties in the development of a psychological picture of themselves.

2. Children of divorced parents use mechanisms for defense in their behavior.

3. Children of divorced parents have increased the feeling of insecurity and low selfconfidence.

4. Children of divorced parents keep silent as a way of dealing with a problem.

\section{ACKNOWLEDGEMENTS}

The authors would like to express their gratitude to all parents and children's who participated in this study.

\section{Conflict of interests}

Authors declare no conflict of interest.

\section{REFERENCES}

Arendell, T. (2000). Conceiving and investigating motherhood: The decade's scholarship. Journal of marriage and family, 62(4), 1192-1207.

Berger J. (2002). Psihološki potporni sistem, Drustvo psihologa Srbije, Beograd.

Block, J. H., Block, J., \& Gjerde, P. F. (1986). The personality of children prior to divorce: A prospective study. Child development, 827-840.

Džuli Lin-Evans. (2009). Razvod, a sta sa decom?, Filozofski Institut, Beograd.

Frojd, A. (2004). Ja i mehanizmi odbrane, Akademska knjiga, Novi Sad.

Cratch, D. and R. S. Cratchfild (1976). Elementi psihologije, Naucna knjiga, Beograd.

Machover, K. (1949). Personality projection in the drawing of the human figure (A method of personality investigation).

Rot, N. (1980). Osnovi socijalne psihologije, Socijalizacija, peto izdanje, Zavod za udžbenike i nastavna sredstva, Beograd. 
(IJCRSEE) International Journal of Cognitive Research in Science, Engineering and Education Vol. 3, No.2, 2015. 